\title{
OPEM
}

www.opem.org

Oriental Pharmacy and Experimental Medicine 2009 9(2), 200-205

DOI 10.3742/OPEM.2009.9.2.200

\section{Secondary metabolites (Triterpenes) from Couroupita guianensis}

\author{
Rokeya Begum ${ }^{1, \dagger}$, Mohammad S Rahman ${ }^{2}$, A M Sarwaruddin Chowdhury ${ }^{1}$, Choudhury M Hasan ${ }^{2}$ \\ and Mohammad A Rashid ${ }^{2,3, *}$ \\ ${ }^{I}$ Department of Applied Chemistry and Chemical Technology, Faculty of Engineering and Technology, University of \\ Dhaka, Dhaka-1000, Bangladesh; ${ }^{2}$ Department of Pharmaceutical Chemistry, Faculty of Pharmacy, University of \\ Dhaka, Dhaka-1000, Bangladesh; ${ }^{3}$ Centre for Biomedical Research, University of Dhaka, Dhaka-1000, Bangladesh
}

Received for publication January 14, 2008; accepted January 07, 2009

\begin{abstract}
SUMMARY
The $n$-hexane and carbon tetrachloride soluble fractions of a methanolic extract of the stem bark

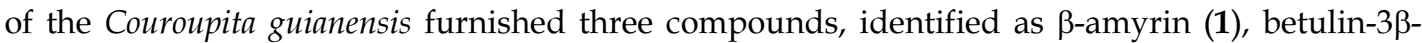
caffeate (2) and lupeol-3 $\beta$-caffeate (3). The structures of the isolated compounds were deduced by extensive spectroscopic analysis as well as by comparison with published values. Compounds 1-3 were subjected to antioxidant screening through free radical scavenging activity by DPPH $(1,1-$ diphenyl-2-picrylhydrazyl), where compound 2 showed moderate antioxidant activity with $\mathrm{IC}_{50}$ value $108.0 \mu \mathrm{g} / \mathrm{ml}$.
\end{abstract}

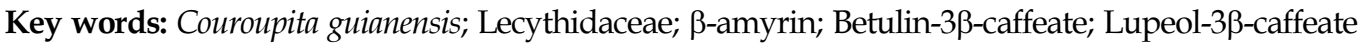

\section{INTRODUCTION}

The plant Couroupita guianensis (English name- Cannon ball tree, local names-Nagalingam, Shibalingam) belonging to the family of Lecythidaceae is an evergreen tree and it is planted in road sides of different districts of Bangladesh (Haque, 1986). The plant of this genus is used for treating skin diseases of livestock by the local Indian (Usher, 1984). Various parts of $C$. guianensis are known to exhibit antifungal activity (Khan et al., 2003). Previous chemical investigations of C. guianensis revealed

*Correspondence: Mohammad A Rashid; Department of Pharmaceutical Chemistry, Faculty of Pharmacy, University of Dhaka, Dhaka-1000, Bangladesh; Tel: +88028612069, 966190073, Fax: +88028612069; E-mail: rashidma@aitlbd.net, rashid_phdu@yahoo.com

'On leave from Department of Agricultural Chemistry, Sher-e-Bangla Agricultural University, Dhaka-1207, Bangladesh. the occurrences of 6,12-dihydro-6,12-dioxoindolo$[2,1-b]$ quinazoline (tryptanthrin), indigo, indirubin, isatin (Bergman et al., 1985), couropitone, $\beta$-amyrin, $\beta$-amyrone, $\beta$-amyrin acetate, stigmasterol, ergosta4,6,8(14),22-tetraen-3-one, $\beta$-sitosterol and its glycoside (Anjaneyulu, 1998; Dictionary of natural products, 2001). This paper details the isolation and structure elucidation of three triterpenoids $\beta$-amyrin (1),

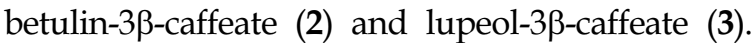
Although $\beta$-amyrin has been previously documented from $C$. guianensis, this is the first report of

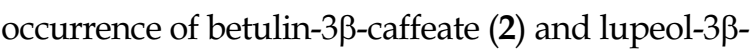
caffeate (3) from this plant.

\section{MATERIALS AND METHODS}

\section{General experimental procedure}

NMR spectra were acquired by using Ultra Shield Bruker DPX 400 NMR instruments. The ${ }^{1} \mathrm{H}$ and ${ }^{13} \mathrm{C}$ 
spectra were recorded in $\mathrm{CDCl}_{3}$ and chemical shifts are reported in ppm with respect to residual non deuterated solvent signals. Mass spectra were recorded on a LCT premier KD146 mass spectrometer using positive mode ESI technique.

\section{Plant material}

The plant $C$. guianensis was collected from Sher-eBangla Agricultural University campus, Sher-eBangla Nagar, Dhaka-1207 in May 2006 and was taxonomically identified by Dr. Mahbuba Khanam, Director, Bangladesh National Herbarium, Ministry of Environment and Forest, Dhaka, Bangladesh where a voucher specimen has been maintained for this collection (accession number is DACB32,062). The stem barks were cut into small pieces, cleaned, dried and pulverized.

\section{Extraction and isolation}

The powdered stem bark (410 g) of C. guianensis was soaked in 1.51 methanol for 5 days with occasional shaking and stirring. Then the extract was filtered and concentrated using a rotary evaporator at low temperature and reduced pressure. A portion $(5 \mathrm{~g})$ of the concentrated methanol extract was fractionated by the modified kupchan (Vanwagenen et al., 1993) procedure into $n$-hexane, carbon tetrachloride, chloroform and aqueous soluble fractions. Evaporation of solvents afforded n-hexane $(1.1 \mathrm{~g})$, carbon tetrachloride $(1.6 \mathrm{~g})$, chloroform $(1.5 \mathrm{~g})$ and aqueous soluble $(0.6 \mathrm{mg})$ materials. The $n$-hexane and carbon tetrachloride soluble materials were separately subjected to vacuum liquid chromatography (VLC) over silica gel $60 \mathrm{H}$ and the columns were eluted with $n$ hexane-ethyl acetate mixtures of increasing polarities with 20 fractions collected for $100 \mathrm{ml}$ each. Evaporation of solvents from the VLC fraction eluted with $40 \%$ ethyl acetate in $n$-hexane of the $n$-hexane soluble materials provided crystalline mass of compound $1(20 \mathrm{mg})$. VLC fraction eluted with $35 \%$ ethyl acetate in $n$-hexane obtained from the carbon tetrachloride soluble materials were further fractionated by gel permeation chromatography over lipophilic Sephadex LH-20 using $n$-hexanedichloromethane-methanol (2:5:1) mixture as the mobile phase. TLC of these fractions demonstrated the presence of two prominent bands in subfractions $\mathrm{f}-26$ and $\mathrm{f}-34$. Sub-fractions $\mathrm{f}-26$ and $\mathrm{f}-34$ were again subjected to preparative TLC over silica gel $\mathrm{PF}_{254}$ using $n$-hexane ethyl-acetate acetic acid (85:15:few drops) and (75:25:few drops) as the developing solvents to yield compound 2 (17.7 $\mathrm{mg})$ and compound 3 (7.6 mg), respectively.

\section{Compounds isolated}

$\beta$-amyrin (1): White amorphous; $\mathrm{C}_{30} \mathrm{H}_{50} \mathrm{O}$ (ESIMS: $m / z[\mathrm{M}+\mathrm{H}]^{+}$427.4282); ${ }^{1} \mathrm{H} \mathrm{NMR}\left(400 \mathrm{MHz}, \mathrm{CDCl}_{3}\right.$ ) $\delta 5.12(1 \mathrm{H}, \mathrm{t}, J=3.5, \mathrm{H}-12), 3.23(1 \mathrm{H}, \mathrm{dd}, J=11.0,5.0$, H-3â), 1.12 (3H, s, $\left.\mathrm{H}_{3}-27\right), 0.98$ (3H, s, $\left.\mathrm{H}_{3}-23\right), 0.96$ $\left(3 \mathrm{H}, \mathrm{s}, \mathrm{H}_{3}-26\right), 0.92\left(3 \mathrm{H}, \mathrm{s}, \mathrm{H}_{3}-24\right), 0.86\left(3 \mathrm{H}, \mathrm{s}, \mathrm{H}_{3}-\right.$ 30), $0.86\left(3 \mathrm{H}, \mathrm{s}, \mathrm{H}_{3}-29\right), 0.82\left(3 \mathrm{H}, \mathrm{s}, \mathrm{H}_{3}-28\right), 0.78(3 \mathrm{H}$, $\left.\mathrm{s}, \mathrm{H}_{3}-25\right)$.

Betulin-3ß-caffeate (2): Brown solid mass; $\mathrm{C}_{39} \mathrm{H}_{56} \mathrm{O}_{5}$ (ESIMS: $m / z[\mathrm{M}+\mathrm{H}]^{+}$605.3871); ${ }^{1} \mathrm{H}$ NMR $\left(400 \mathrm{MHz}, \mathrm{CDCl}_{3}\right): \delta 7.54\left(1 \mathrm{H}, \mathrm{d}, J=15.0 \mathrm{~Hz}, \mathrm{H}-3^{\prime}\right)$, 7.09 (1H, br s, H-6"), 6.98 (1H, d, J = 8.0 Hz, H-2"), $6.85(1 \mathrm{H}, \mathrm{d}, J=8.0 \mathrm{~Hz}, \mathrm{H}-5 "), 6.24(1 \mathrm{H}, \mathrm{d}, J=15.0$ Hz, H-2'), 4.67 (1H, br. s, $\left.\mathrm{H}_{\mathrm{a}}-29\right), 4.60\left(1 \mathrm{H}, \mathrm{m}, \mathrm{H}_{\alpha}-3\right)$, $4.58\left(1 \mathrm{H}, \mathrm{br} \mathrm{s}, \mathrm{H}_{\mathrm{b}}-29\right), 3.81\left(1 \mathrm{H}, \mathrm{d}, J=10.8 \mathrm{~Hz}, \mathrm{H}_{\mathrm{a}}-\right.$ 28), $3.35\left(1 \mathrm{H}, \mathrm{d}, J=10.8 \mathrm{~Hz}, \mathrm{H}_{\mathrm{b}}-28\right), 2.37(1 \mathrm{H}, \mathrm{m}, \mathrm{H}-$ 19), 1.68 (3H s, $\left.\mathrm{H}_{3}-30\right), 1.01\left(3 \mathrm{H}, \mathrm{s}, \mathrm{H}_{3}-26\right), 0.98(3 \mathrm{H}$, $\left.\mathrm{s}, \mathrm{H}_{3}-27\right), 0.90\left(3 \mathrm{H}, \mathrm{s}, \mathrm{H}_{3}-23\right), 0.87\left(3 \mathrm{H}, \mathrm{s}, \mathrm{H}_{3}-25\right), 0.86$ $\left(3 \mathrm{H}, \mathrm{s}, \mathrm{H}_{3}-24\right) .{ }^{13} \mathrm{C}$ NMR: $\delta 38.4(\mathrm{C}-1), 23.8(\mathrm{C}-2), 81.3$ (C-3), 38.1 (C-4), 55.4, (C-5), 18.2 (C-6), 34.2 (C-7), 40.9 (C-8), 50.3 (C-9), 37.1 (C-10), 27.0 (C-11), 25.2 (C-12), 37.3 (C-13), 42.7 (C-14), 20.8 (C-15), 29.2 (C16), 47.8 (C-17), 48.8 (C-18), 47.8 (C-19), 150.3 (C20), 29.7 (C-21), 34.1 (C-22), 28.0 (C-23), 16.7 (C-24), 16.2 (C-25), 16.0 (C-26), 14.8 (C-27), 60.7 (C-28), 109.8 (C-29), 19.1 (C-30), 167.8 (C-1'), 114.4 (C-2'), 146.6 (C-3'), 127.4 (C-1"), 122.3 (C-2"), 144.0, (C-3"), 146.6 (C-4"), 116.0 (C-5"), 122.3 (C-6").

Lupeol-3 $\beta$-caffeate (3): Brown solid mass; $\mathrm{C}_{39} \mathrm{H}_{56} \mathrm{O}_{4}$ (ESIMS: $\left.m / z[\mathrm{M}+\mathrm{H}]^{+} 589.4429\right) ;{ }^{1} \mathrm{H} \mathrm{NMR}(400 \mathrm{MHz}$, $\left.\mathrm{CDCl}_{3}\right): \delta 7.54\left(1 \mathrm{H}, \mathrm{d}, J=15.0 \mathrm{~Hz}, \mathrm{H}-3^{\prime}\right), 7.10(1 \mathrm{H}, \mathrm{br}$ 
s, H-6"), $6.99\left(1 \mathrm{H}, \mathrm{d}, J=8.0 \mathrm{~Hz}, \mathrm{H}-2^{\prime \prime}\right), 6.86(1 \mathrm{H}, \mathrm{d}, J$ $\left.=8.0 \mathrm{~Hz}, \mathrm{H}-5^{\prime \prime}\right), 6.25\left(1 \mathrm{H}, \mathrm{d}, J=15.0 \mathrm{~Hz}, \mathrm{H}-2^{\prime}\right), 4.68$ (1H, br. s, $\left.\mathrm{H}_{\mathrm{a}}-29\right), 4.59\left(1 \mathrm{H}, \mathrm{m}, \mathrm{H}_{\alpha}-3\right), 4.57(1 \mathrm{H}, \mathrm{br} \mathrm{s}$, $\left.\mathrm{H}_{\mathrm{b}}-29\right), 2.36$ (1H, m, H-19), 1.68 (3H s, $\left.\mathrm{H}_{3}-30\right), 1.03$ $\left(3 \mathrm{H}, \mathrm{s}, \mathrm{H}_{3}-26\right), 0.98\left(3 \mathrm{H}, \mathrm{s}, \mathrm{H}_{3}-27\right), 0.90\left(3 \mathrm{H}, \mathrm{s}, \mathrm{H}_{3^{-}}\right.$ 23), $0.87\left(3 \mathrm{H}, \mathrm{s}, \mathrm{H}_{3}-25\right), 0.87\left(3 \mathrm{H}, \mathrm{s}, \mathrm{H}_{3}-24\right), 0.78(3 \mathrm{H}$, s, $\left.\mathrm{H}_{3}-28\right) .{ }^{13} \mathrm{C}$ NMR: $\delta 38.4$ (C-1), 23.8 (C-2), 81.3 (C3), 38.1 (C-4), 55.4 (C-5), 18.2 (C-6), 34.2 (C-7), 40.9 (C-8), 50.4 (C-9), 37.1 (C-10), 21.0 (C-11), 25.1 (C12), 38.1 (C-13), 42.8 (C-14), 27.4 (C-15), 35.6 (C-16), 43.0 (C-17), 48.3 (C-18), 48.0 (C-19), 150.9 (C-20), 29.8 (C-21), 40.0 (C-22), 28.0 (C-23), 16.6 (C-24), 16.2
(C-25), 16.0 (C-26), 14.5 (C-27), 18.0 (C-28), 109.3 (C29), 19.3 (C-30), 167.6 (C-1'), 116.3 (C-2'), 144.5 (C3'), 127.7 (C-1"), 115.5 (C-2"), 143.8 (C-3"), 146.2 (C4"), 114.4 (C-5"), 122.3 (C-6").

\section{Antioxidant activity}

The antioxidant activity (free radical scavenging activity) of the purified compounds on the stable radical 1,1-diphenyl-2-picrylhydrazyl (DPPH) was determined by the method developed by BrandWilliams et al., 1995. In the experiment, $2.0 \mathrm{mg}$ of each of the compounds 1-3 were dissolved in<smiles>CC1(C)CCC2C3CCC4C(C)(C)CC[C@H](O)C4(C)C3(C)CCC2(C)CC1</smiles>

1

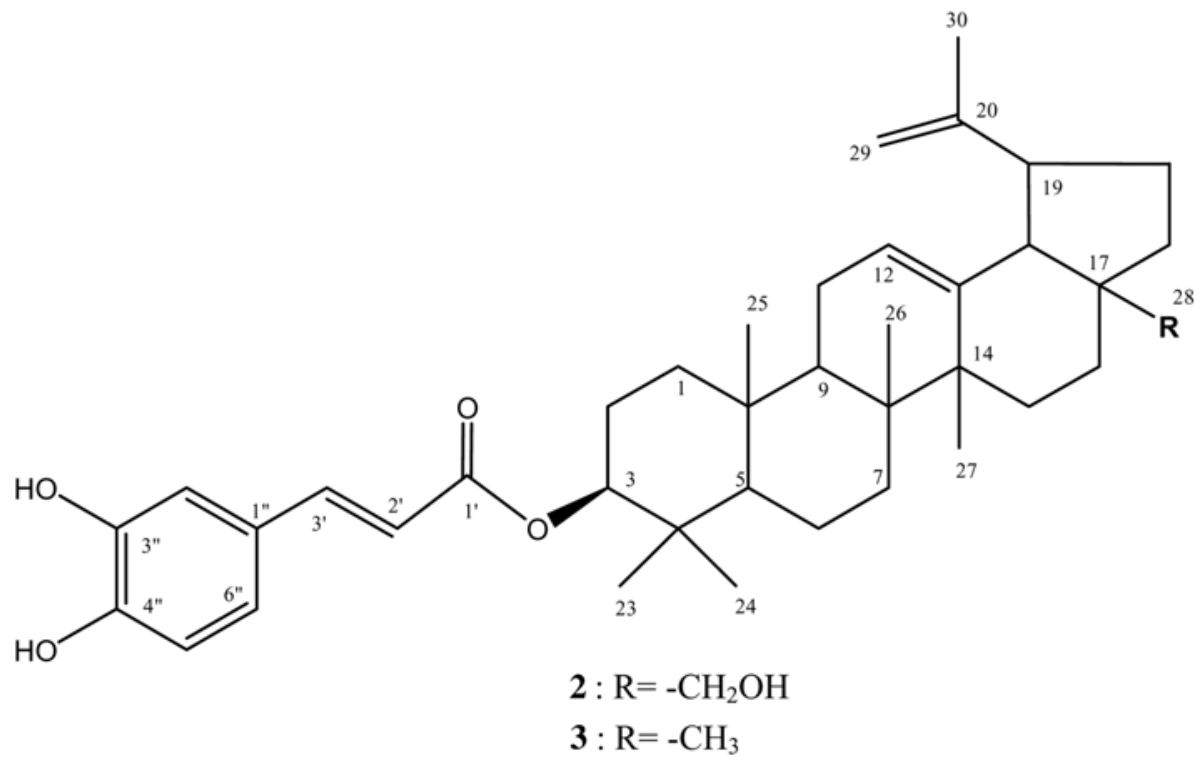


methanol. Solution of varying concentrations such as $500 \mu \mathrm{g} / \mathrm{ml}, 250 \mu \mathrm{g} / \mathrm{ml}, 125 \mu \mathrm{g} / \mathrm{ml}, 62.50 \mu \mathrm{g} / \mathrm{ml}$, $31.25 \mu \mathrm{g} / \mathrm{ml}, 15.62 \mu \mathrm{g} / \mathrm{ml}, 7.8125 \mu \mathrm{g} / \mathrm{ml}, 3.91 \mu \mathrm{g} /$ $\mathrm{ml}, 1.95 \mu \mathrm{g} / \mathrm{ml}$ and $0.98 \mu \mathrm{g} / \mathrm{ml}$ were obtained by serial dilution technique. $2 \mathrm{ml}$ of a methanol solution of the extractive of each concentration was mixed with $3 \mathrm{ml}$ of a DPPH-methanol solution $(20 \mu \mathrm{g} / \mathrm{ml})$ and was allowed to stand for 20 minutes for the reaction to occur. Then the absorbance was determined at $517 \mathrm{~nm}$ and from these values the corresponding percentage of inhibitions were calculated by using the following equation:

$\%$ inhibition $=\left[1-\left(\mathrm{ABS}_{\text {sample }} / \mathrm{ABS}_{\text {control }}\right)\right] \times 100$

Then $\%$ inhibitions were plotted against respective concentrations used and from the graph the $\mathrm{IC}_{50}$ was calculated. Here, tert-butyl-1-hydroxytoluene (BHT), a potential antioxidant, was used as positive control. The assay was conducted in triplicate and $\mathrm{IC}_{50}$ values were calculated as mean $\pm \mathrm{SD}(\mathrm{n}=3)$.

\section{RESULTS}

Extensive chromatographic separation and purification of $n$-hexane and carbon tetrachloride soluble materials of the methanolic extract of the stem bark of $C$. guianensis provided three compounds (1-3). The structures of the isolated compounds were elucidated as $\beta$-amyrin (1), betulin-3 $\beta$-caffeate (2) and lupeol-3 $\beta$-caffeate (3) by extensive NMR and mass spectral analyses. The purified compounds 13 were subjected to antioxidant screening through free radical scavenging activity by 1,1-diphenyl-2-

Table 1. $\mathrm{IC}_{50}$ values of compounds 1-3 and tert-butyl1-hydroxytoluene

\begin{tabular}{cc}
\hline Samples & $\mathrm{IC}_{50}(\mu \mathrm{g} / \mathrm{ml})^{*}$ \\
BHT & $19.0 \pm 0.33$ \\
$\beta$-amyrin (1) & -- \\
Betulin-3 $\beta$-caffeate (2) & $108.0 \pm 1.11$ \\
Lupeol-3 $\beta$-caffeate (3) & $121.0 \pm 1.25$ \\
\hline *The values of $\mathrm{IC}_{50}$ are expressed as mean $\pm \mathrm{SD}(\mathrm{n}=3) ;$ \\
BHT: tert-butyl-1-hydroxytoluene (Std.)
\end{tabular}

picrylhydrazyl (DPPH) and by using tert-butyl-1hydroxytoluene (BHT) as standard. The $\mathrm{IC}_{50}$ values of these compounds are shown in Table 1.

\section{DISCUSSION}

The ESI mass spectrum of compound 1 exhibited the pseudo-molecular ion peak at $\mathrm{m} / \mathrm{z} 427.4282$ which was consistent with a molecular formula $\mathrm{C}_{30} \mathrm{H}_{50} \mathrm{O}$ for this compound. Its ${ }^{1} \mathrm{H}$ NMR spectrum displayed eight methyl singlets at $\delta 1.12,0.98,0.96$, $0.92,0.86(2 \times \mathrm{Me}), 0.82$ and 0.78 . The C-3 oxymethine proton resonance was seen at $\delta 3.23(\mathrm{dd}, J=11.0$, $5.0 \mathrm{~Hz})$, while the olefinic proton triplet $(J=3.5 \mathrm{~Hz})$ at $\delta 5.12$ was attributed to $\mathrm{H}-12$. This suggested the presence of a triterpenoid skeleton of the $\beta$-amyrin series. Comparison of the spectral data with published values confirmed the identity of compound $\mathbf{1}$ as $\beta$-amyrin (Thanakijcharoenpath and Theanphong, 2007; Ercil et al., 2004).

Compound 2 was obtained as amorphous mass. The electro-spray ionization ((ESI) mass spectrum of 2 displayed a pseudo-molecular ion peak at $\mathrm{m} / \mathrm{z}$ 605.3871 suggesting a molecular formula $\mathrm{C}_{39} \mathrm{H}_{56} \mathrm{O}_{5}$ for this compound. The ${ }^{13} \mathrm{C}$ NMR spectrum $(125$ $\mathrm{MHz}, \mathrm{CDCl}_{3}$ ) of 2 displayed 39 carbon resonances, while DEPT and HSQC experiments indicated that 31 out of the 39 carbons had attached protons. This ${ }^{13} \mathrm{C}$ NMR spectral data was consistent with the molecular formula of this compound. The ${ }^{1} \mathrm{H} N \mathrm{NM}$ spectrum showed signals at $\delta 7.09$ (1H br. s), $6.85 \mathrm{~d}$ $(1 \mathrm{H}, \mathrm{d}, J=8.0 \mathrm{~Hz})$ and $6.98(1 \mathrm{H} \mathrm{d}, J=8.0 \mathrm{~Hz})$ together with a pair of trans-olefinic $(J=15.0 \mathrm{~Hz})$ protons resonating at $\delta 6.24$ and 7.54 indicated the presence of a para-caffeate moiety. The ${ }^{1} \mathrm{H}$ NMR spectrum also revealed a triterpene type carbon skeleton of the lupine series with two exomethylene proton resonances at $\delta 4.67\left(1 \mathrm{H}, \mathrm{br}, \mathrm{s}, \mathrm{H}_{\mathrm{a}}-29\right)$ and $4.58(1 \mathrm{H}$, br, $\mathrm{s} \mathrm{H}_{\mathrm{b}}$-29), which together with an allylic methyl at $\delta 1.68\left(3 \mathrm{H}, \mathrm{br}, \mathrm{s}, \mathrm{H}_{3}-30\right)$ confirmed an isoprenyl functionality. In addition, the ${ }^{1} \mathrm{H}$ NMR spectrum also displayed five tertiary methyl singlets at $\delta 0.86$, $0.87,0.90,0.98$ and 1.01 assignable to the methyl 
groups at C-24, C-25, C-23, C-27 and C-26, respectively by comparison with the spectral data of lupeol, lupeol acetate and betulin-3 $\beta$-caffeate (Aratanechemuge et al, 2003; Patra et al., 1988; Chen et al., 1999). In addition, the ${ }^{1} \mathrm{H}$ NMR spectrum exhibited an $\mathrm{AB}$ quartet with doublets $(J=10.8)$ centered at $\delta 3.81$ and 3.35 for the non-equivalent geminal protons of a hydroxymethyl $\left(-\mathrm{CH}_{2} \mathrm{OH}\right)$ group. The $\mathrm{C}-3$ oxymethine proton was evident as a multiplet at $\delta 4.60$, partially overlapped with one of the exomethylene protons. The down field nature of this signal could be explained by an esterification with the para caffeate moiety. The equatorial alpha $(\alpha)$ nature of the C-3 oxygenated substituent follows from the spin coupling pattern of the oxymethine proton, H-3. The occurrence of the H-3 resonance at $\delta 4.60$ rather than at $\delta 3.20$ as in lupeol suggested C-3 as the esterification site in compound 2 . The ${ }^{13} \mathrm{C}$ resonance of C-3 at $\delta 81.3$ in compound 2 rather than at $\delta 79.0$ in lupeol further confirmed that the para-caffeate moiety was linked to C-3 of the triterpene skeleton. In contrast, the chemical shift positions for the hydroxymethyl protons and its carbon ( $\delta$ 60.7) remained almost unchanged as compared to those of betulin (Siddiqui et al., 1988; Mahanto et al., 1994). The location of the trans para-caffeate moiety at $\mathrm{C}-3$ of the triterpene skeleton was also substantiated by both ${ }^{1} \mathrm{H}$ and ${ }^{13} \mathrm{CNMR}$ spectral data of compound 2 with those of betulin-33-caffeate (Pan et al., 1994). From the above spectral data and by comparing these data with published values (Chen et al., 1999), compound 2 was identified as betulin-3 $\beta$-caffeate. Although betulin-3 $\beta$-caffeate has previously been reported from various plants but this is the first report of its occurrence from C. guianensis.

The electro-spray ionization (ESI) mass spectrum of compound 3 displayed a pseudo-molecular ion peak at $m / z 589.4429$ appropriate for a molecular formula $\mathrm{C}_{39} \mathrm{H}_{56} \mathrm{O}_{4}$. The ${ }^{13} \mathrm{C} N M R$ spectrum $(125 \mathrm{MHz}$, $\mathrm{CDCl}_{3}$ ) showed 39 carbon resonances, consistent with the molecular formula of this compound. The ${ }^{13} \mathrm{C}$ and the ${ }^{1} \mathrm{H}$ NMR spectra of compound 3 were almost identical to those of compound 2 . Thus, it showed signals characteristic of a lupane-type triterpene and a para-caffeate moiety. However, the ${ }^{1} \mathrm{H}$ NMR spectrum of the compound displayed six tertiary methyl resonances instead of five observed in betulin-3 $\beta$-caffeate. On the other hand, the hydroxymethyl group resonances observed in the ${ }^{1} \mathrm{H}$ and ${ }^{13} \mathrm{C}$ spectra of betulin-3 $\beta$-caffeate at $\delta 3.35$ and $3.81(\delta \mathrm{c} 60.7)$ were absent in the spectra of compound 3 . The absence of the hydroxymethyl group signals in NMR spectra of compound 3 and the presence of 6 tertiary methyl signals instead of 5 observed in betulin-3 $\beta$-caffeate allowed the characterization of compound $\mathbf{3}$ as lupeol-3 $\beta$-caffeate. The identity of compound $\mathbf{3}$ as lupeol-3 $\beta$-caffeate was further confirmed by comparison of its NMR and MS data with literature values (Alvarenga and Ferro,

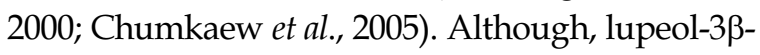
caffeate has previously been reported from many plants but this is the first report of its occurrences in C. guianensis.

In case of screening for antioxidant activity (Table 1), compound 2 showed the highest antioxidant activity with $\mathrm{IC}_{50}$ value of $108.0 \mu \mathrm{g} / \mathrm{ml}$. At the same time, compound 3 exhibited moderate antioxidant activity $\left(\mathrm{IC}_{50}=121.0 \mu \mathrm{g} / \mathrm{ml}\right)$, whereas compound 1 displayed no free radical scavenging activity.

\section{ACKNOWLEDGEMENTS}

Authors wish to thank the Bose centre for advanced study and research in natural sciences, University of Dhaka for partial financial support for carrying out the research.

\section{REFFERENCES}

Alvarenga N, Ferro EA. (2000) A new lupane caffeoyl ester from Hippocratea volubilis. Fitoterapia 71, 719721.

Anjaneyulu, ASRSS. (1998) A new ketosteroid from the bark of Couroupita guianensis Aubl. Indian J. Chem. 37, 382-386.

Bergman J, Lindström J, Tilstam U. (1985) The structure and properties of some indolic constituents 
in Couroupita guianensis aubl. Tetrahedron 41, 28792881.

Chen B, Duan H, Takaishi Y. (1999) Triterpene caffeoyl esters and diterpenes from Celastrus stephanotifolius. Phytochemistry 51, 683-687.

Chumkaew P, Kato S, Chantrapromma K. (2005) A New Triterpenoid Ester from the Fruits of Bruguiera parviflora. Chem. Pharm. Bull. 53, 95-96.

Dictionary of Natural Products on CD-ROM, version 9.2, Chapman \& Hall, 2001.

Ercil D, Sakar MK, Olmo ED, Feliciano AS. (2004) Chemical Constituents of Linaria aucheri. Turkish J. Chem. 28, 133-139.

Haque AM. (1986) Plant names of Bangladesh. Bangladesh National Herbarium. Ministry of Environment and Forest, Dhaka, Bangladesh. p. 137, 214.

Khan MR, Kihara M, Omoloso AD. (2003) Antibiotic Activity of Couroupita guianensis. J. Herbs Spices Med.
Plants 10, 95-108.

Mahanto SB, Kundu AP. (1994) ${ }^{13}$ C NMR spectra of pentacyclic triterpenoids-acompilation and some salient features. Phytochemistry 37, 1517-1575.

Pan H, Lundgren LN, Andersson R. (1994) Triterpene caffeates from bark of Betula pubescens. Phytochemistry 37, 795-799.

Siddiqui S, Hafeez F, Begum S, Siddiqui BS. (1988) A new pentacyclic triterpene from the leaves of Nerium oleander. J. Nat. Prod. 51, 229-233.

Thanakijcharoenpath W, Theanphong O. (2007) Triterpenoids from the stem of Diospyros glandulosa. Thai J. Pharm. Sci. 31, 1-8.

Usher G. (1984) A dictionary of plants. CBS publishers and distributors, Delhi. p.180.

Vanwagenen BC, Larsen R, Cardellina, JH II, Randazzo D, Lidert ZC, Swithenbank C. (1993) Ulosantoin, a potent insecticide from the sponge Ulosa ruetzleri. J. Organic Chem. 58, 335-337. 